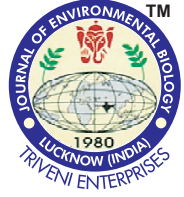

DOI : http://doi.org/10.22438/jeb/39/4/MRN-519

\title{
Bioefficacy of antimicrobial peptide biosynthesis-gene-linked antagonistic Lysinibacillus sphaericus strains for management of bacterial plant diseases in Andaman and Nicobar Islands, India
}

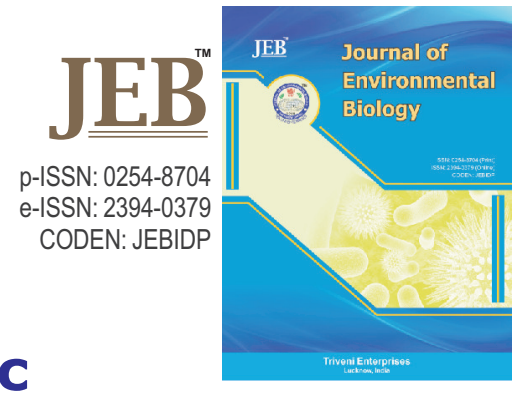

Authors Info

K. Sakthivel ${ }^{1 *}$, K. Manigundan, R.K. Gautam', P.K. Singh', Yogeshwari', T. Subramani ${ }^{1}$, S.K. Sharma ${ }^{2}$ and R. Khande

${ }^{1}$ Division of Field Crop Improvement and Protection, ICAR- Central Island Agricultural Research Institute, Andaman \& Nicobar Islands-744 101, India

${ }^{2}$ National Agriculturally Important Microbial Culture Collection, ICARNational Bureau of Agriculturally Important Microorganisms, Mau Nath Bhanjan - 275 001, India

${ }^{3}$ Department of Biotechnology, Barkatullah University, Bhopal-462 026, India

${ }^{*}$ Corresponding Author Email : veluars@gmail.com

Key words

Antagonistic activity AMP biosynthesis genes Biological control Lysinibacillus sphaericus Rhizosphere soil

Publication Info

Paper received : 23.11.2016 Revised received : 11.05.2017

Re-revised received : 22.08.2017 Accepted : 13.10.2017

\begin{abstract}
Aim : The present study aimed to investigate the bioefficacy of antimicrobial peptide-gene-linked antagonistic Lysinibacillus sphaericus strains isolated from Andaman and Nicobar Islands, India for controlling diseases in plants.
\end{abstract}

Methodology : Bacillus spp. isolated from different niches of Andaman \& Nicobar Islands were characterized for antimicrobial and PGP- traits. The identity of potential isolates was confirmed by 16SrRNA gene sequence analysis. Biocontrol potential of selected isolates against chili bacterial wilt pathogen was tested in glasshouse conditions. The antimicrobial peptide biosynthesis genes responsible for antagonistic activities of Lysinibacillus sphaericus strains were analysed by PCR based methods.

Results : Out of fifty two isolates tested, two Lysinibacillus sphaericus strains (Ls_Agu and NS2) collected from Nicobar sea sand and chili crop rhizosphere of South Andaman Islands were found good in in-vitro antagonistic potential against important plant bacterial pathogens: Ralstonia solanacearum (solanaceous bacterial wilt) and Xanthomonas oryzae pv. oryzae (rice bacterial blight) using an agar diffusion assay. In glasshouse study, both the strains Ls_Agu and NS2 showed significant biocontrol efficacy $(88.9 \%$ and $66.7 \%)$ against Ralstonia solanacearum, which causes bacterial wilt disease in chili. The antimicrobial potential of these strains were further ascertained by presence of three AMP biosynthesis genes (surfactin, bacilysin and fengycin) in both the strains through PCR amplification.

Interpretation : The overall results revealed the antimicrobial peptide-genelinked strains Ls_Agu and NS2 of $L$. sphaericus have ability to control bacterial plant disease under Islands conditions and the same strains could be utilized for popularization on Islands for management of the bacterial diseases.
Collection of soil samples from rhizosphere and non-rhizophere soils of Andaman \& Nicobar Islands

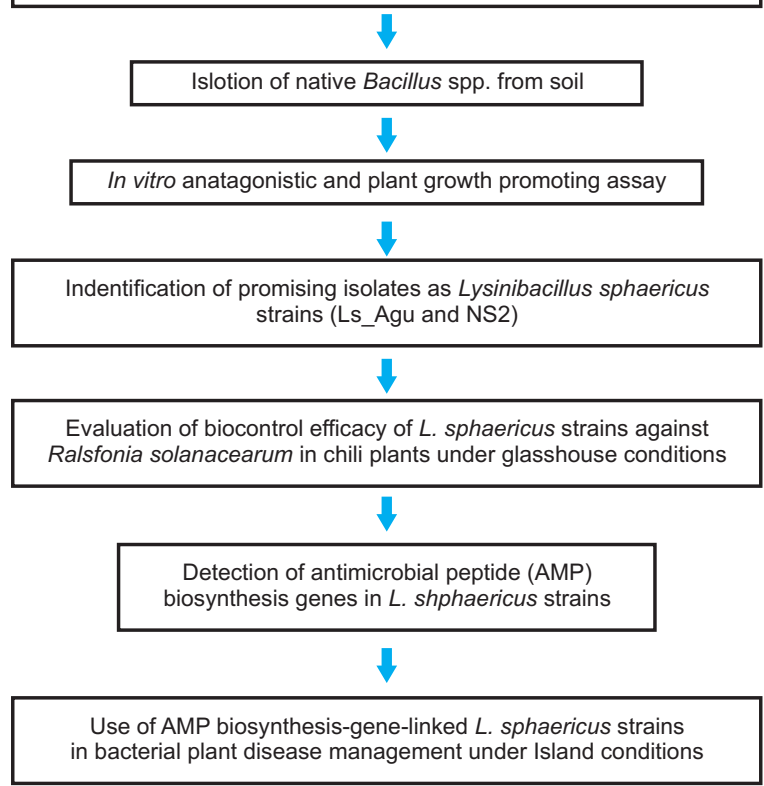




\section{Introduction}

The members of bacterial genus Bacillus comes under phylum Firmicutes are the most characterized group among bacterial community and among which Lysinibacillus is one such member having Gram-positive, rod-shaped, round and spore forming nature in the family Bacillaceae. Lysinibacillus is commonly found in soil, plants and animals (Hayat et al., 2013) and around 23 species of industrial purpose have been reported worldwide till date. Few of the Lysinibacillus spp. have been reported for their nitrogen fixing ability (Reghuvaran et al., 2012), plant growth promoting activities (Vendan et al., 2010) and biological control against fungal pathogens (Ahmad and Khan, 2015). But originally the Lysinibacillus sphaericus were earlier reported for its potential of utilizing as larvicidal agents against mosquito (Wirth et al., 2013) having insecticidal toxin that controls mosquito growth. The management of bacterial plant diseases is very important worldwide. Non availability of suitable chemicals, high cost of antibiotics and emergence of multi drug resistant bacteria have made the management of phyto-bacterial diseases highly challenging and complex. Recent reports have highlighted the successful utilization of native antagonistic bacterial species against important plant diseases in many regions of the world.

Out of several mechanisms, the production of antimicrobial peptides (AMPs) was found to be very important bio-control mechanism of plant pathogen in several Bacillus species (Gonzalez-Sanchez et al., 2010). Bacillus species contain as many as 24 diverse AMP genes that allow the biosynthesis of antibiotics like iturin, bacilysin, bacillomycin, fengycin, surfactin, mersacidin, ericin, subtilin, subtilosin and mycosubtilin (Chung et al.. 2008). The presence of a greater number of AMP genes has been correlated with the efficiency of antagonist in controlling plant pathogens (Mora et al., 2011). Among Bacillus community, B. subtilis/amyloliquefaciens are primarily well known for the presence of antimicrobial peptide (AMPs) biosynthetic genes and their byproducts which are advocated to be directly involved in antimicrobial activities against plant pathogens (Athukorala et al., 2009) and thus have been recommended as a potential biocontrol agents. Meager studies on biocontrol activity of Lysinibacillus against plant bacterial pathogens and studies on its AMP biosynthesis genes. In this study, native strains of Lysinibacillus sphaericus isolated from Andaman and Nicobar Islands were evaluated for their invitro antagonistic potential against two important bacterial pathogens Ralstonia solanacearum (solanaceous bacterial wilt pathogen) and Xanthomonas oryzae pv. oryzae: (rice bacterial blight pathogen) followed by detection of antimicrobial peptide (AMPs) biosynthesis genes in two strains.

\section{Materials and Methods}

Isolation of bacteria : A total of 52 Bacillus like bacteria were isolated from rhizosphere of crops and non-rhizosphere soils collected from different locations of Andaman and Nicobar Islands using semi-selective isolation procedure (Travers et al., 1987). The two bacterial isolates which showed consistent plant growth promoting (PGP) and in-vitro antagonistic activities were identified using 16S rRNAgene sequencing.

Evaluation of in-vitro antagonistic potential and plant growth promoting traits : The antagonistic activity of these two potential strains were tested in-vitro against the highly virulent bacterial pathogen strains $R$. solanacearum strain CRs_Sg1 and $X$. oryzae strain ANBB_16 collected from culture collections of ICAR-CIARI, Port Blair using agar well diffusion assay on King's medium Briefly, in agar diffusion test, $48 \mathrm{hr}$ old grown $R$. solanacearum or $X$. oryzae pv. oryzae strains were mixed in King's medium B $(0.25$

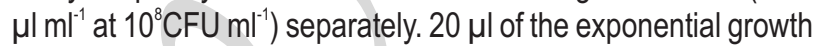
phase of antagonistic culture (approximately $3.5 \times 10^{8} \mathrm{CFU} \mathrm{ml}^{-1}$ ) was added in $7 \mathrm{~mm}$ wells in the plates and sterile water was used as negative control in the experiment. The experiment was repeated thrice and the antagonistic ability was recorded as inhibition zone around the well (radius in $\mathrm{mm}$ ) after $48 \mathrm{hr}$. The plant growth promoting traits like siderophore production (Schwyn and Neilands, 1987), indole acetic acid (Gordon and Weber, 1951) and phosphate solubilization (Nautiyal, 1999) were evaluated in vitro as mentioned.

Detection of antimicrobial peptide (AMPs) biosynthesis genes : To study the presence of AMP biosynthesis genes, the genomic DNA was extracted from antagonistic Lysinibacillus sphaericus strains by standard procedures (Sambrook and Russell, 2001). A set of sixteen primers were used for PCR screening. PCR amplifications were carried out in $50 \mu$ reaction mixtures at C1000TM Thermal Cycler (Bio-Rod) with the following cycle conditions: initial denaturation at $95^{\circ} \mathrm{C}$ for $15 \mathrm{~min}$; 40 cycles of $95^{\circ} \mathrm{C}$ for $1 \mathrm{~min}, 55^{\circ} \mathrm{C}$ or $52^{\circ} \mathrm{C}$ for $1 \mathrm{~min}$, and $72^{\circ} \mathrm{C}$ extension for $1.5 \mathrm{~min}$; and a final extension at $72^{\circ} \mathrm{C}$ for $7 \mathrm{~min}$. A total of $5 \mu \mathrm{l}$ of each amplification reaction was analyzed by electrophoresis using $1.5 \%$ agarose gel, followed by ethidium bromide staining and visualized in Gel-documentation system (Bio-Rad).

Evaluation of antagonist potential against $R$. solanacearum : The in-planta bio-control efficacy of both the strains was tested against chili bacterial wilt pathogen Ralstonia solanacearum in glass house condition as per Ramesh et al., (2012) with slight modifications. The virulent pathogen strain CRs_Sg1 was collected from culture collection center, Plant Pathology Laboratory, CIARI, Port Blair. Thirty day old chili plants (Capsicum annuum) were transferred to $15 \mathrm{~cm}$ diameter plastic pots containing sterilized potting mixture of 2:1:1 (Red soil: FYM: Sand) and maintained in glass house conditions. After acclimatization for one week period, freshly prepared bio-control bacterial suspension of $50 \mathrm{ml}\left(10^{8} \mathrm{cfu} \mathrm{ml}^{-1}\right)$ was poured into the soil at the base of each plant. One week after inoculation of bio control, a $20 \mathrm{ml}$ suspension of $R$. solanacearum strain $\left(5 \times 10^{7} \mathrm{cfu}\right.$ $\mathrm{ml}^{-1}$ ) was poured into the soil to give a final bacterial concentration 
of $10^{6} \mathrm{cfu} \mathrm{g}^{-1}$ d.wt. In total, four treatments were followed (Two treatments with antagonistic bacteria + pathogenic bacteria, one treatment of pathogenic bacteria alone and another with normal water). All the treated plants were incubated at $28^{\circ}-32^{\circ} \mathrm{C}$ and at 80-90\% RH under glasshouse conditions for wilt development up to 30 days. Three replications were maintained per treatment with nine chili plants in three pots/ treatment. Wilt incidence was recorded at weekly intervals up to one month and wilting percentage was calculated at the end of the experiment by the formula given by Guo et al. (2004). The disease incidence and biocontrol efficiency was also calculated.

\section{Results and Discussion}

A total of 52 Bacillus like isolates were obtained from rhizosphere and non-rhizosphere soil samples of Andaman and Nicobar Islands, India (Data not shown). All the isolates were screened for in-vitro antagonistic and PGP traits and subsequently two potential isolates were selected for further inplanta and PCR analysis. The genetic identity of two isolates was confirmed as Lysinibacillus sphaericus using 16S rRNA gene sequence analysis (GenBank accession KP864632 and KJ013550).

The in-vitro studies using agar diffusion results revealed that both the Lysinibacillus sphaericus isolates were having high
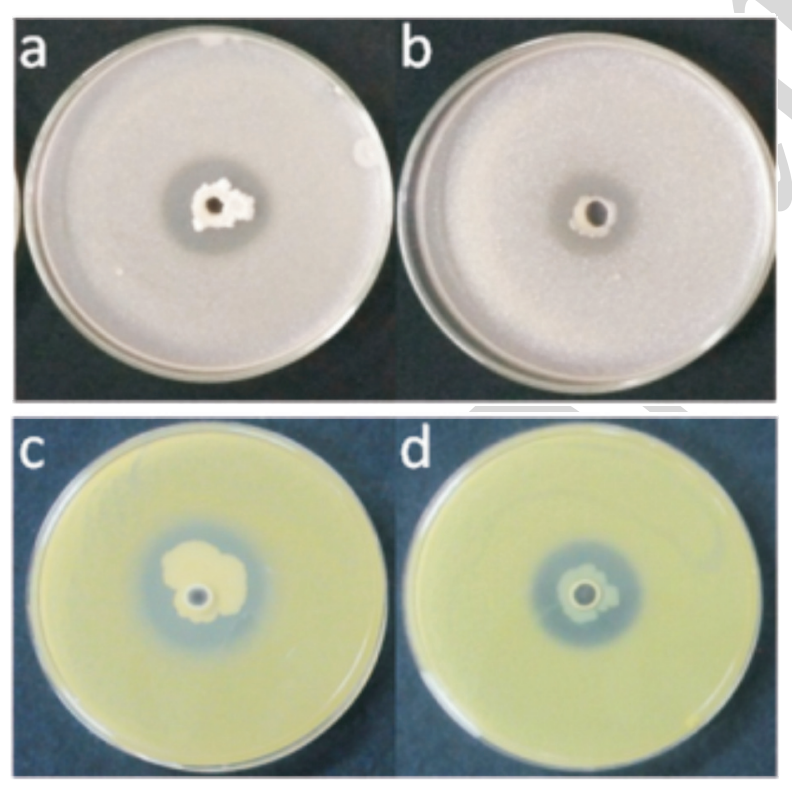

Fig. 1 : In-vitro antagonistic activity of Lysininibacillus spp. against $R$. solanacearum strain CRs_Sg1and X. oryzae pv. oryzae strainANBB_16

\section{Legends:}

$\mathrm{a} \& \mathrm{~b}$-Ls_Agu and NS2 strain against $R$. solanacearum strain $C R s \_S g 1$ $c \& d-L s \_$Agu and NS2 strain against $X$. oryzae strain ANBB_16 potential of antagonism against both the plant bacterial pathogens tested. For solanaceous bacterial wilt pathogen $R$. solanacearum, Ls_Agu and NS2 showed inhibition zone of 10.06 $\mathrm{mm}$ and $9.33 \mathrm{~mm}$ whereas for rice bacterial blight pathogen $X$. oryzaepv. oryzae, the zone of inhibition was $15.17 \mathrm{~mm}$ and 12.68 $\mathrm{mm}$, respectively (Fig. 1). Among PGP traits tested, both the isolates were found to be good siderophore producers, whereas in contrast no $\mathrm{P}$ solubilization and IAA productions were noted. This study is in the line of work described by Hakizimana et al. (2011), wherein Lysinibacillus fusiformis was identified as a potential biocontrol agent as it showed biocontrol activity against Phytophthora cinnamomi. Also the strain of Lysinibacillus fusiformis was reported to be positive for most of the plant growth promoting traits, indicating their role in growth promotion of ginseng (Vendan et al., 2010). In the present study, for the first time siderophore production and in vitro antagonistic potential in L. sphaerecus was recorded.

Earlier the role of AMP genes in conferring better antagonistic activity was reported in many Bacillus spp. by several studies (Chung et al., 2008, Kim et al., 2010 and Shanthiyaa et al., 2015). The antimicrobial peptide genes (AMPs) which encompass cyclic lipopeptides such as bacillomycin, fengycin, iturin and surfactin etc., play a vital role in antagonistic efficacy of genus Bacillus which has been again linked to the presence of the AMP biosynthetic genes such as bmyB, fenD, ituC and sifA. However, no reports available related to presence of AMP biosynthesis genes in Lysinibacillus strains and their role in imparting antibacterial antagonism earlier. In the present study the PCR analysis for AMP biosynthesis genes revealed the presence of three AMP biosynthesis genes viz., surfactin, bacilysin and fengycininin in the Ls_Agu and NS2 strains (Table 1). The strain

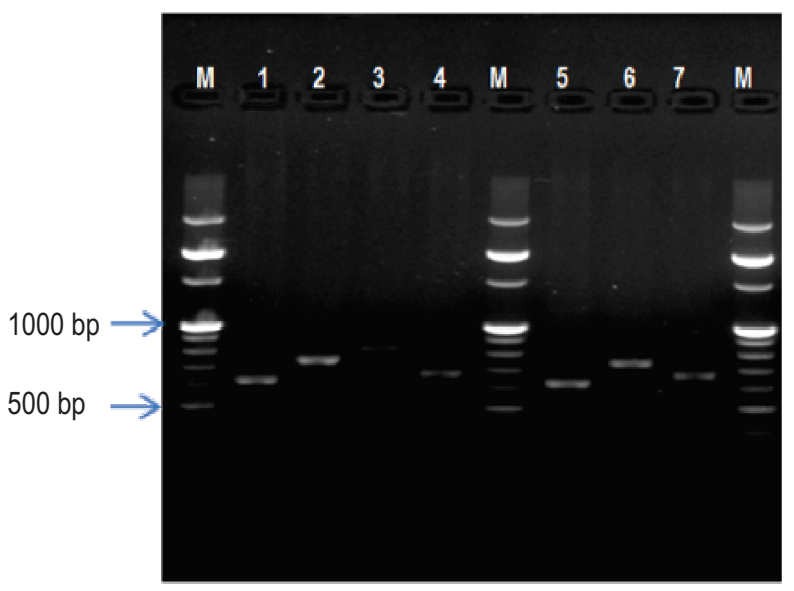

Fig. 2 : Amplification of AMP biosynthesis genes in L. sphaericus strains. Lane M is a 100-bp ladder. Lane 1 to 4 is Ls_Agu and Land 5 to 7 is NS2. Lanes 1 and 5 - surfactin; Lanes 2, 3 and 6 - bacilysin and Lanes 4 and 7 fengycin 
Table 1: Detection of antibiotic biosynthesis genes in Lysinibacillus sphaericus strains

\begin{tabular}{|c|c|c|c|c|c|c|}
\hline Antibiotics & $\begin{array}{l}\text { Genes } \\
\text { symbol }\end{array}$ & Primers & Sequences & $\begin{array}{l}\text { PCR product } \\
\text { (bp) }\end{array}$ & $\begin{array}{l}\text { L. sphaericus } \\
\text { size (Ls_Agu) }\end{array}$ & $\begin{array}{l}\text { L. sphaericus } \\
\text { Ns2 }\end{array}$ \\
\hline \multirow[t]{2}{*}{ Surfactin } & sifA & SRFA-F1 & 5'-AGAGCACATTGAGCGTTACAAA & 626 & Yes & Yes \\
\hline & & SRFA-R1 & 5'-CAGCATCTCGTTCAACTTTCAC & & & \\
\hline \multirow[t]{4}{*}{ Bacilysin } & bacD & BACD-F1 & 5'-AAAAACAGTATTGGTYATCGCTGA & 749 & Yes & Yes \\
\hline & & BACD-R1 & 5'-CCATGATGCCTTCKATRCTGAT & & & \\
\hline & bacAB & BACAB-F1 & 5'-CTTCTCCAAGGGGTGAACAG & 815 & Yes & No \\
\hline & & BACAB-R1 & 5'-TGTAGGTTTCACCGGCTTTC & & & \\
\hline \multirow[t]{2}{*}{ Fengycin } & fenB & FENB-F1 & 5'-CCTGGAGAAAGAATATACCGTACCY & 670 & Yes & Yes \\
\hline & & FENB-R1 & 5'-GCTGGTTCAGTTKGATCACAT & & & \\
\hline
\end{tabular}

Table 2 : Antagonistic efficacy of Lysinibacillus sphaericus strains (Ls_Agu and Ns2) against Ralstonia solanacearum strain CRs_Sg1 under glasshouse conditions after 30 days of growth period

\begin{tabular}{lll}
\hline Treatments & \multicolumn{2}{l}{ Antagonistic efficacy (\%) } \\
& Wilt incidence & Biocontrol efficacy \\
\hline Ls_Agu + pathogen & 16.67 & 83.33 \\
Ns2 + pathogen & 33.33 & 66.67 \\
Pathogen alone (control) & 100.0 & - \\
Normal water & 0 & - \\
\hline
\end{tabular}

Ls_Agu amplified with four primer sets whereas strain NS2 with three primer pairs (Fig. 2). This might also be one of the strong reasons for the effective antagonistic efficacy of both the strains against Ralstonia solanacearum and Xanthomonas oryzae pv. oryzae.

The in-planta glass house studies (Table 2) revealed the antagonistic strains Ls_Agu (16.67\%) and NS2 (33.33\%) showed significant reduction in disease incidence at 30 days after bacterial inoculation when compared to pathogen inoculated treatments (100\%). The bio-control efficiency of Ls_Agu and NS2 was $83.33 \%$ and $66.7 \%$, respectively, when compared to water control $(0 \%)$ in greenhouse. Though the biocontrol potential of endophytic Lysinibacillus spp. against fungal plant pathogens have been reported earlier (Hakizimana et al., 2011), the antibacterial antagonism potential is being reported for the first time in this study. Earlier, the antagonistic potential against multiple plant pathogens using bacilli was reported by many researchers. Chung et al. (2008) reported that Bacillus subtilis strain ME488 could suppress the growth of 39 out of 42 plant pathogens tested using in-vitro antagonistic assay. Recently, Sakthivel et al. (2017) reported that Bacillus subtilis strain Bs_Ane from Neil Island, India showed better antagonistic potential (growth inhibition) against three phytopathogens, Ralstonia solanacearum, Xanthomonas oryzae and Colletotrichum gloeosporioides.

This study indicated that the Lysinibacillus sphaericus strains Ls_Agu and NS2 identified from Andaman \& Nicobar
Islands with broad spectrum antagonistic traits would be a potential source for utilizing them in successful eco-friendly management of plant diseases in the Islands and to the best of our knowledge this is the first study on antibacterial efficacy of Lysinibacillus strains possessing antimicrobial peptide biosynthesis genes.

\section{Acknowledgments}

The research of sub-project entitled "Exploring Antimicrobial Peptide Genes in Developing Bio-formulation for the Management of Plant Disease of Andaman and Nicobar Islands" operating at ICAR-CIARI, Port Blair, Andaman and Nicobar Islands, India was supported by grants from the main project entitled "Microbial Diversity Analysis of Extreme Niches" under scheme "Application of Microorganisms for Agriculture and Allied Sectors" of ICAR, New Delhi, India.

\section{References}

Ahmad, V. and M.S. Khan: Therapeutic intervention and molecular characterizations of bacteriocin producing Lysinibacillus sp., nov., isolated from food sample. Pak. J. Pharm. Sci., 28, 1337-1344 (2015).

Athukorala, S.N.P., W.G.D. Fernando and K.Y. Rashid: Identification of antifungal antibiotics of Bacillus species isolated from different microhabitats using polymerase chain reaction and MALDI-TOF mass spectrometry. Can. J. Microbiol., 55, 1021 (2009).

Chung, S., H. Kong, J.S. Buyer, D.K. Lakshman, L. J. Lydon, S.D. Kim and D.P. Roberts: Isolation and partial characterization of Bacillus subtilis ME488 for suppression of soil borne pathogens of cucumber and pepper. Appl. Microbiol. Biotechnol., 80, 115-123 (2008).

Gonzalez-Sanchez, M.A., R.M. Perez-Jimenez, C. Pliego, C. Ramos, A. De Vicente and F.M. Cazorla: Biocontrol bacteria selected by a direct plant protection strategy against avocado white root rot show antagonism as a prevalent trait. J. Appl. Microbiol., 109, 65-78 (2010).

Gordon, S.A and R.P. Weber: Colorimetric estimation of indole-acetic acid. Plant Physiol., 26, 192-195 (1951).

Hakizimana, J.D., M. Gryzenhout, T.A. Coutinho and V.D.N. Berg: Endophytic diversity in Persea americana (avocado) trees and their ability to display biocontrol activity against Phytophthora 
cinnamomi. Proceedings VII World Avocado Congress, (Actas VII Congreso Mundial delAguacate) Cairns, Australia (2011).

Hayat, R., I. Ahmed, J. Peak, E. Muhammad, I. Muhammad and Y.H. Chang: A moderately boron tolerant candidatus novel soil bacterium Lysinibacillus pakistanensis $\mathrm{sp}$. Nov. cand., isolated from soybean (Glycine max. L) rhizosphere. Pak. J. Bot., 45, 41-50 (2013).

Kim, P.I., J. Ryu, Y.H. Kim and Y.T. Chi: Production of biosurfactantli popeptideslturin A, Fengycin and Surfactin A from Bacillus subtilis CMB32 for control of Colletotrichum gloeosporioides. J. Microbiol. Biotechnol., 20, 138-145(2010).

Maor, R., S. Haskin, H. Levi-Kedmi and A. Sharon: In planta production of indole-3-acetic acid by Colletotrichum gloeosporioides $\mathrm{f}$. sp. aeschynomene. App. Environ. Microbiol., 70, 1852-1854 (2004).

Mora, I., J. Cabrefiga and E. Montesinos: Antimicrobial peptide genes in Bacillus strains from plant environments. Int. Microbiol., 14, 213-223 (2011).

Nautiyal, C.S., S. Bhadauria, P. Kumar, H. Lal, R. Mondal and D. Verma: Stress induced phosphate solubilization in bacteria isolated from alkaline soils. FEMS Microbiol. Lett., 182, 291-296 (2000).

Ramesg, R. and G.S. Phakde: Rhizosphere and endophytic bacteria for the suppression of eggplant wilt caused by Ralstonia solanacearum. Crop Protect., 37, 35-41 (2012).

Reghuvaran, A., K.K. Jacob and A.D. Ravindranath: Isolation and characterization of nitrogen fixing bacteria from raw coir pith. Afr. J. Biotechnol., 11, 7063-7071 (2012).

Sakthivel K., K. Manigundan, R. K. Gautam, I. Jaisankar, S.K. Sharma, R. Singh and S.D. Roy: Detection of antimicrobial peptides genes from antagonistic Bacillus subtilis (Bs_Ane) isolated from Neil Islands of Andaman, India. J, Environ. Biol., 38, 75-80 (2017).

Sambrook, J and D.W. Russell: Molecular cloning; a Laboratory Manual. Cold Spring Harbor Laboratory, New York (2001).

Schwyn, B and J.B. Neilands: Universal chemical assay for the detection and determination of siderophores. Analytical Biochem., 160, 4756 (1987).

Shanthiyaa, V., G. Karthikeyan, T. Raguchander and K. Prabakar: Identification of antifungal antibiotics genes of Bacillus species strain from different microhabitats using polymerase chain reaction. Afr. J. Microbiol. Res., 9, 280-285 (2015).

Travers, R.S., P.A.W. Martin and C.F. Reichelderfer: Selective isolation of soil Bacillus spp. Appl. Environ.Microbiol., 53, 1263 (1987).

Vendan, R.T., Y.J. Yu, S.H. Lee and Y.H. Rhee: Diversity of endophytic bacteria in ginseng and their potential for plant growth promotion. J. Microbiol., 48, 559-565 (2010).

Wirth, M., C. Berry, W.E. Walton and B.A. Federici: Mtx toxins from Lysinibacillus sphaericus enhance mosquitocidal cry-toxin activity and suppress cry resistance in Culex quinquefaciatus. J. Inverteb. Pathol., 115, 62-67 (2013). 